\title{
Non-V600 BRAF mutations recurrently found in lung cancer predict sensitivity to the combination of Trametinib and Dabrafenib
}

\author{
Amir Noeparast ${ }^{1}$, Erik Teugels ${ }^{1}$, Philippe Giron ${ }^{1}$, Gil Verschelden ${ }^{1}$, Sylvia De \\ Brakeleer $^{1}$, Lore Decoster ${ }^{1}$, Jacques De Grève ${ }^{1}$ \\ ${ }^{1}$ Laboratory of Molecular Oncology and Department of Medical Oncology, Oncologisch Centrum, UZ Brussel, Vrije Universiteit \\ Brussel, Brussels, Belgium \\ Correspondence to: Jacques De Grève, email: jacques.degreve@uzbrussel.be \\ Keywords: non-V600 BRAF, lung cancer, impaired-kinase, Trametinib, Dabrafenib \\ Received: October 08, $2015 \quad$ Accepted: June 09, $2016 \quad$ Published: August 26, 2016 \\ Copyright: Noeparast et al. This is an open-access article distributed under the terms of the Creative Commons Attribution License \\ 3.0 (CC BY 3.0), which permits unrestricted use, distribution, and reproduction in any medium, provided the original author and \\ source are credited.
}

\section{ABSTRACT}

Approximately half of BRAF-mutated Non-small cell lung cancers (NSCLCs) harbor a non-V600 BRAF mutation, accounting for 40,000 annual deaths worldwide. Recent studies have revealed the benefits of combined targeted therapy with a RAF-inhibitor (Dabrafenib) and a MEK-inhibitor (Trametinib) in treating V600 BRAF mutant cancers, including NSCLC. In contrast, sensitivity of non-V600 BRAF mutations to these inhibitors is not documented. Non-V600 mutations can either increase or impair BRAF kinase activity. However, impaired BRAF kinases can still activate the ERK pathway in a CRAF-dependent manner. Herein, beyond describing a cohort of BRAF mutant NSCLC patients and functionally analyzing 13 tumor-derived BRAF mutations, we demonstrate that both types of non-V600 BRAF mutations can be sensitive to clinically relevant doses of Dabrafenib and Trametinib in HEK293T cells, in lung epithelial cellular model (BEAS-2B) and in human cancer cell lines harboring non-V600 BRAF mutations. ERK activity induced by both types of these mutations is further reduced by combinatorial drug treatment. Moreover, the combination leads to more prolonged ERK inhibition and has anti-proliferative and pro-apoptotic effects in cells harboring both types of non-V600 BRAF mutations. This study provides a basis for the clinical exploration of non-V600 BRAF mutant lung cancers upon treatment with Trametinib and Dabrafenib.

\section{INTRODUCTION}

BRAF mutations are found in $\sim 8 \%$ of human cancers and occur in 6-8\% of non-small cell lung cancers (NSCLCs) $[1,2]$. Although cancers such as melanoma predominantly have V600 BRAF mutations, non-V600 BRAF mutations are very common in NSCLC [2-6]. Lung cancers with a non-V600 BRAF mutation are predicted to account for approximately 40,000 annual deaths worldwide [2, 7].

V600 mutated BRAF has constitutively high kinase activity towards its downstream effector, mitogen/ extracellular signal-regulated kinase (MEK), which in turn results in strong activation of extracellular-signal-regulated kinase (ERK) [8]. High kinase activity towards MEK due to V600 mutations has also been shown in non-cellular systems $[6,9,10]$. Some non-V600 BRAF mutations confer high kinase activity in cell-free assays, while other non-V600 mutations result in impaired kinase activity. However, kinase-impairing BRAF mutations still induce ERK pathway activation when wild-type CRAF, a heterodimerization partner of BRAF, is also present in the cell [9].

The ERK pathway is the major deregulated pathway associated with BRAF-mutated cancers. ERK pathway inhibition has been shown to have anti-proliferative effects in cells harboring both kinase-activating and impairing BRAF mutations [10-13].

Over the last decade, BRAF-targeted therapies and drug development have focused specifically on inhibition of $\mathrm{V} 600 \mathrm{E}$ mutated BRAF, mainly due to the high proportion of $\mathrm{V} 600 \mathrm{E}$ mutations in melanoma.

The need for potent and selective RAF inhibitors led to the development of type I RAF inhibitors such 
as Vemurafenib and Dabrafenib. In contrast to type II inhibitors, such as Sorafenib, these drugs inhibit RAF by binding to its active conformation. These drugs also inhibit the kinase activity of wild-type RAFs in cell-free assays [14-16]. However, type I RAF-inhibitors induce RAF dimerization in RAF wild-type cells in which RAF monomers are in an inactive state. RAF dimerization leads to transactivation and hyperactivation of the inhibitorfree RAF protomer, ultimately resulting in ERK pathway activation. This "paradoxical ERK activation" occurs with non-saturating doses of RAF inhibitors and is dependent on the presence of CRAF [17-20].

Importantly, paradoxical ERK activation is associated with manifestation of cutaneous squamouscell carcinoma and keratoacanthoma in patients treated with RAF inhibitors [1, 17, 18]. Another challenge with RAF-inhibitor monotherapy is early adaptive insensitivity to these drugs. Early adaptive insensitivity to RAF inhibitors in V600E-mutated cells is characterized by a RAF inhibitor-induced shift from RAF monomeric to dimeric signaling, in parallel with relief of negative ERK feedback. Reactivated ERK has been shown to be MEK inhibitor sensitive [21-24]. In the long term, early adaptive insensitivity to RAF inhibitors can favor secondary and more permanent resistance mechanisms, such as CRAF overexpression or RAS mutations, leading to complete resistance to these drugs [21, 23, 25-27].

Despite initially promising clinical results in V600E BRAF-mutated melanoma, Vemurafenib and Dabrafenib monotherapies ultimately end with drug resistance and relapse of the cancer [27-30].

In melanoma patients harboring BRAF-V600 mutations, a combination of Dabrafenib with the allosteric MEK inhibitor Trametinib has been shown to improve overall survival and decrease the risk of adverse events related to paradoxical ERK activation when compared to Vemurafenib and Dabrafenib monotherapy, although ultimately combined therapy also ends with resistance [22-24, 27, 29, 31, 32].

The benefit of combined therapy with Dabrafenib and Trametinib has been demonstrated in V600 BRAF mutated melanoma, NSCLC and colorectal cancer (CRC). In contrast, non-V600 BRAF mutations have not been included in clinical trials with selective RAF and/or MEK inhibitors [29, 33-35]; this limitation could be due to the small proportion of patients harboring non-V600 BRAF mutations in melanoma. In addition, many non-V600 BRAF mutations are kinase-impaired and thus considered unattractive for RAF-targeted therapy.

As ERK activation in both classes of non-V600 BRAF mutations is RAF and MEK dependent and cells harboring such mutations have been shown to be addicted to ERK activity [10-13], we hypothesized that these mutations confer sensitivity to combined RAF and MEK targeting.

In the present study, we first describe a cohort of NSCLC patients identified with BRAF mutations. Then, we functionally analyze a set of 13 different BRAF mutations derived from this cohort and supplemented with mutations reported previously by others in NSCLC patients. Finally, we examine the effects of clinically relevant doses of Dabrafenib and/or Trametinib on HEK293T cells co-expressing mutant BRAFs with wtCRAF and human cancer cell lines harboring non-V600 BRAF mutations.

\section{RESULTS}

\section{Patient characteristics and BRAF mutation genotypes}

A total of 229 NSCLC patients underwent molecular testing for the presence of EGFR, ERBB2, KRAS, NRAS, HRAS and BRAF mutations between January 2006 and December 2014.

Twelve patients $(5.2 \%)$ were found to harbor seven different BRAF mutations. All the identified BRAF mutations were missense single nucleotide substitutions. Of the seven identified nucleotide substitutions, six were transversion events and 1 was a transition (Table 1, 2 \& Figure 1A).

The mean age at the time of diagnosis for NSCLC patients with a BRAF mutation was 68.4 years (range between 47 and 88 years), which was comparable to the 72 years of the non-BRAF mutated patients. The gender ratio of BRAF-mutated NSCLC patients was 1:1. All patients identified with BRAF mutations had metastatic disease. Eight out of 12 NSCLC patients harboring a BRAF mutation were current or former smokers. The four BRAFmutated NSCLC patients with a non-smoking history were female. Patient characteristics are summarized in Table 1. According to the patients' performance status and tolerance pattern, a platinum-based chemotherapy (cis or carboplatin) was chosen in combination with pemetrexed. Taking into account age, prognosis and comorbidity considerations, gemcitabine was administered instead of classical platinum-based schedules for some patients. The mean overall survival of the BRAF-mutated NSCLC patients was 7.4 months (range between 1 and 16 months, Supplementary Figure S1).

\section{Characterization of BRAF mutations}

To characterize the seven NSCLC-derived BRAF mutations identified in our clinical samples and to test the sensitivity of a broader subset of non-V600 BRAF mutations to ERK pathway inhibitors, we generated 13 BRAF-expressing plasmids (in our cohort, supplemented by NSCLC mutations reported by others, recombinant $\mathrm{BRAF}$ proteins are $3 \mathrm{X}$ flag-tagged and are referred to as flag-BRAF for simplicity). Three of our mutations, D594E, D594N and G596C, were previously reported but not characterized. G469V was previously considered to be an activating mutation, without being characterized [36]. 
Table 1: Clinical characteristics of Belgian patients found with BRAF mutations

\begin{tabular}{|c|c|c|c|c|c|c|c|c|c|}
\hline Patients & $\begin{array}{c}B R A F \\
\text { mutation }\end{array}$ & $\begin{array}{l}\text { Nucleotide } \\
\text { substitution }\end{array}$ & $\begin{array}{c}\text { Age at } \\
\text { diagnosis } \\
\text { (years) }\end{array}$ & $\begin{array}{l}\text { Survival } \\
\text { (months) }\end{array}$ & Gender & $\begin{array}{l}\text { Smoking } \\
\text { history }\end{array}$ & TTF1 & Stage & $\begin{array}{c}\text { Firts-line } \\
\text { Treatment }\end{array}$ \\
\hline 1 & D594E & $1782 \mathrm{~T}>\mathrm{G}$ & 47 & 9 & female & non-smoker & - & NA & $\begin{array}{l}\text { Cisplatin + } \\
\text { Gemcitabine }\end{array}$ \\
\hline 2 & G596C & $1786 \mathrm{G}>\mathrm{T}$ & 73 & 2 & male & current & + & IV & NA \\
\hline 3 & D594N & $1780 \mathrm{G}>\mathrm{A}$ & 77 & 8 & male & current & NA & IV & Gemcitabine \\
\hline 4 & D594N & $1781 \mathrm{G}>\mathrm{A}$ & 54 & 16 & female & non-smoker & + & IV & $\begin{array}{c}\text { Cisplatin + } \\
\text { Gemcitabine }\end{array}$ \\
\hline 5 & D594N & $1782 \mathrm{G}>\mathrm{A}$ & NA & 1 & male & former & + & IV & Gemcitabine \\
\hline 6 & G466V & $1397 \mathrm{G}>\mathrm{T}$ & 76 & 7 & male & former & + & IV & $\begin{array}{c}\text { Cisplatin + } \\
\text { Gemcitabine }\end{array}$ \\
\hline 7 & G469V & $1406 \mathrm{G}>\mathrm{T}$ & 70 & 2 & female & former & + & IV & $\begin{array}{c}\text { Carboplatin + } \\
\text { Pemetrexed }\end{array}$ \\
\hline 8 & G469A & $1406 \mathrm{G}>\mathrm{C}$ & 88 & 7 & male & current & + & IV & NA \\
\hline 9 & G469A & $1406 \mathrm{G}>\mathrm{C}$ & 69 & NA & female & non-smoker & NA & IV & $\begin{array}{c}\text { Cisplatin }+ \\
\text { etoposide }\end{array}$ \\
\hline 10 & V600E & $1799 \mathrm{~T}>\mathrm{A}$ & 56 & 9 & female & former & + & IV & NA \\
\hline 11 & V600E & $1799 \mathrm{~T}>\mathrm{A}$ & 58 & 12 & male & current & + & IV & $\begin{array}{c}\text { Carboplatin }+ \\
\text { pemetrexed }\end{array}$ \\
\hline 12 & V600E & $1799 \mathrm{~T}>\mathrm{A}$ & 85 & NA & female & NA & + & NA & NA \\
\hline
\end{tabular}

Abbreviations: TTF1, thyroid transcription factor; NA, not available.

Table 2: Summary of BRAF mutations characterization

\begin{tabular}{|c|c|c|c|c|c|}
\hline Mutation & Exon & $\begin{array}{c}\text { Position in kinase } \\
\text { Domain }\end{array}$ & $\begin{array}{c}\text { kinase activity } \\
\text { towards MEK } \\
\text { (kinase assay) }\end{array}$ & $\begin{array}{c}\text { MEK/ERK } \\
\text { activation } \\
(\text { HEK293T) }\end{array}$ & $\begin{array}{c}\text { Increased MEK/ERK } \\
\text { in presence of CRAF } \\
(\text { HEK293T })\end{array}$ \\
\hline G466V & 11 & p-loop & Impaired & No & Yes \\
\hline G469A & 11 & p-loop & Active & Yes & No \\
\hline G469S & 11 & p-loop & Active & Yes & No \\
\hline G469V & 11 & p-loop & Active & Yes & No \\
\hline D594A & 15 & DFG motif & Impaired & No & Yes \\
\hline D594G & 15 & DFG motif & Impaired & No & Yes \\
\hline D594E & 15 & DFG motif & Impaired & No & Yes \\
\hline D594N & 15 & DFG motif & Impaired & No & Yes \\
\hline D594V & 15 & DFG motif & Impaired & No & Yes (weak) \\
\hline G596C & 15 & DFG motif & Impaired & No & Yes \\
\hline V600E & 15 & A-loop & Active & Yes & No \\
\hline V600K & 15 & A-loop & Active & Yes & No \\
\hline V600R & 15 & A-loop & Active & Yes & No \\
\hline
\end{tabular}

Mutations in bold are found in the subset of Belgian NSCLC patients. 
A

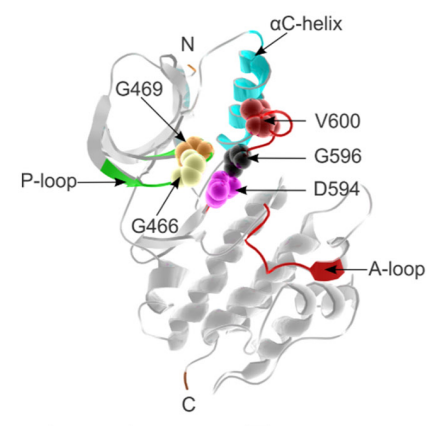

B

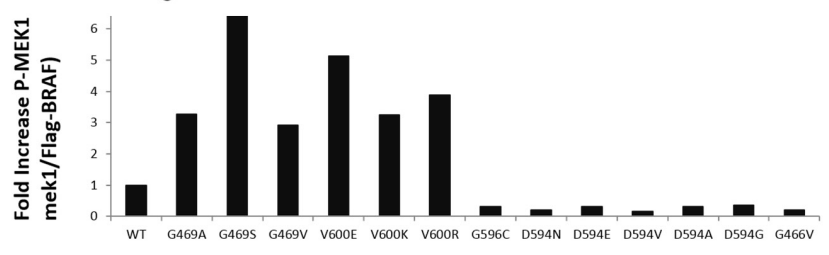

C

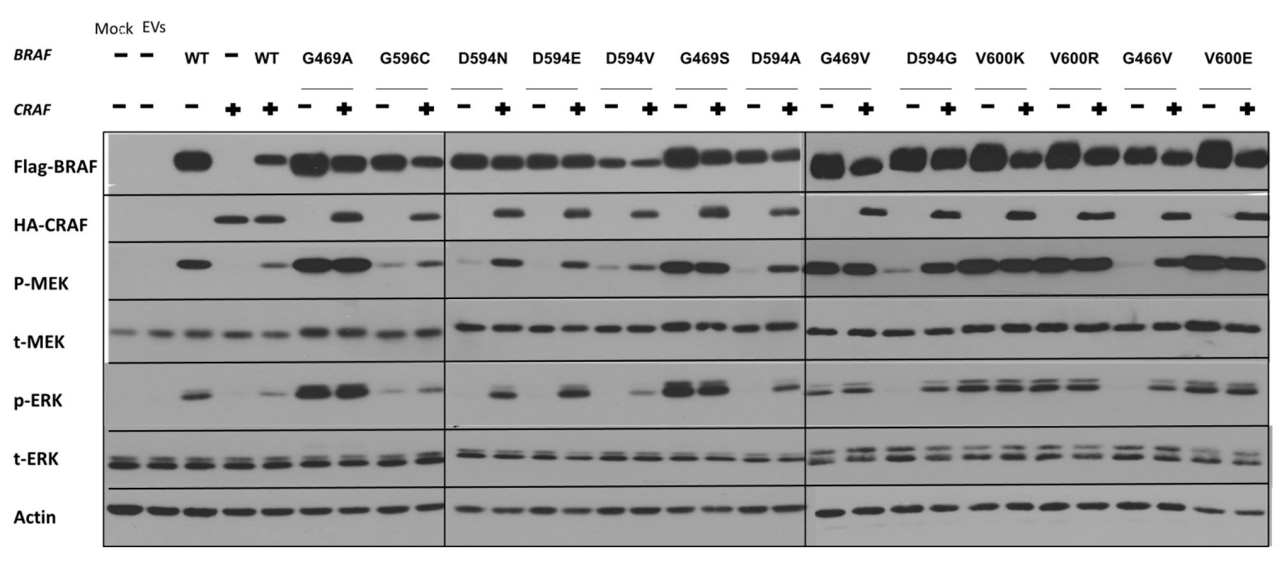

D

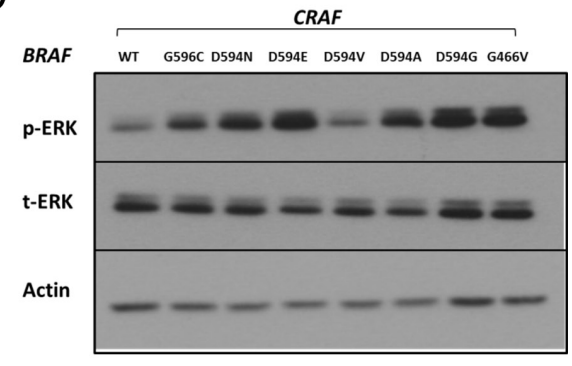

$\mathrm{E}$

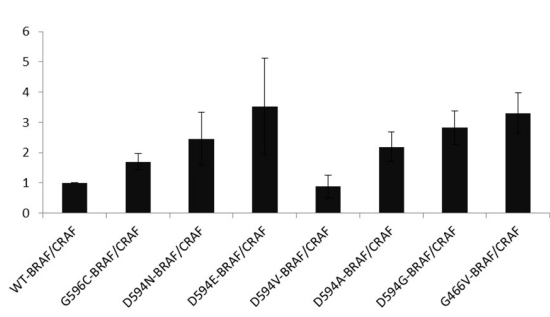

Figure 1: Characterization of BRAF mutations. A. Different amino acid positions targeted by the BRAF mutations investigated in this study are mapped onto the 3D-Structure of the BRAF kinase-domain (PDB:4MBJ) [64], [P-loop: green; A-loop: magenta, alpha-C helix: cyan]. The 5 mutated positions are displayed as magnified van der Waals radii in distinctive colors. B. Equivalent amounts of BRAF proteins were subjected to in vitro kinase assays. For each type of recombinant BRAF protein, p-MEK and Flag-BRAF were quantified by ImageJ after western blotting. p-MEK levels were normalized to the corresponding Flag-BRAF levels, and fold increase over wild-type BRAF is displayed. C. HEK293T cells were transiently transfected with various BRAF expression vectors alone or co-transfected with a CRAF expression vector. Transfected cells were lysed $48 \mathrm{~h}$ post-transfection and subjected to western blot analysis to detect the indicated proteins. D. Comparative assay to determine the relative ERK activation induced by the different BRAF/CRAFs conferring impaired kinase activity. Only D594V BRAF/CRAF shows weaker ERK activity than wt-BRAF/CRAF. E. p-ERK and corresponding actin levels were quantified by Image J, p-ERK levels were normalized to the corresponding actin levels, and fold increase over wt-BRAF/CRAF is displayed. The Means $\pm \mathrm{sd}$ are shown from three independent experiments. $\mathrm{EV}=$ Empty Vectors. When required, western blot bands were quantified by Image $\mathrm{J}$. 


\section{In vitro kinase assay}

Recombinant BRAF mutant proteins were transiently expressed in HEK293T cells, purified by immunoprecipitation and quantified. Purified recombinant BRAF mutant proteins were subjected to in vitro kinase assays to determine their respective kinase activity towards the direct substrate of BRAF, MEK1 (Table $2 \&$ Figure 1B).

Compared to wt-BRAF, the mutations G469A, G469S, G469V, V600E, V600K and V600R showed increased kinase activity towards kinase-dead MEK1. In contrast, G466V, D594A, D594G, D594E, D594N, D594V and G596C were kinase-impaired.

\section{Kinase-active Mutant BRAF induces MEK/ERK pathway activation in HEK293T cells}

To determine the impact of BRAF mutations on the MEK/ERK pathway in a cellular system, FLAG-tagged BRAF mutants were transiently expressed in HEK293T cells. Transfected cells were analyzed by western blot to determine the levels of phospho-MEK and phospho-ERK. Consistent with the results obtained in the in-vitro kinase assays, BRAF mutations G469A, G469S, G469V, V600E, V600K and V600R showed increased p-MEK and p-ERK levels compared to wt-BRAF. The BRAF mutants G466V, D594A, D594G, D594E, D594N, D594V and G596C did not induce MEK or ERK activation compared to wt-BRAF (Figure 1C \& Table 2).

\section{Co-expression of kinase-impaired BRAF and CRAF induces MEK/ERK pathway activation in HEK293T cells}

As previously reported, kinase-impaired BRAF mutants can still activate the ERK pathway in a CRAFdependent manner [9]. To further characterize our mutant BRAF constructs, we co-expressed each mutant BRAF with wt-CRAF in HEK293T cells.

BRAF mutants characterized as kinase-impaired in our in vitro kinase assay, clearly induced phosphorylation of MEK and ERK when co-expressed with CRAF (Figure 1, 1 C \& Table 2). Moreover, with the exception of D594VBRAF/CRAF, higher p-ERK1/2 levels were observed in kinase-impaired-BRAF/CRAF co-transfectants compared to wt-BRAF/CRAF (Figure 1D \& 1E).

\section{Effect of RAF/MEK/ERK pathway inhibitors on non-V600 BRAF mutant-induced ERK signaling}

\section{Inhibitory effect of Dabrafenib on mutant BRAF- induced ERK signaling}

Among the clinically available RAF-inhibitors, Dabrafenib, whose primary target is V600E BRAF, has shown the highest affinity for CRAF in cell-free assays.
The IC50 of Dabrafenib to inhibit CRAF is $~ 10$-fold less than that of Vemurafenib [14-16]. The average maximal plasma concentration of Dabrafenib in treated patients is between $1.5 \mu \mathrm{M}$ and $2.8 \mu \mathrm{M}$ [37]. To investigate the effect of Dabrafenib on ERK signaling induced by different BRAF mutations, we transiently expressed 13 BRAF mutants singly (Figure 2A) or with CRAF (Figure 2B) in HEK293T cells; we then evaluated the ERK activation status after $2 \mathrm{~h}$ of Dabrafenib treatment $(2.5 \mu \mathrm{M})$.

As expected, Dabrafenib treatment of HEK293T cells singly expressing BRAF mutants with elevated kinase activity led to decreased p-ERK1/2 levels (Figure 2A).

Dabrafenib treatment of HEK293T cells coexpressing BRAF mutants (conferring elevated and impaired kinase activity) with CRAF resulted in decreased p-ERK1/2 levels (Figure 2B). The only exception was the impaired kinase BRAF mutant D594V, which showed increased p-ERK levels upon Dabrafenib treatment (Figure 2B). A similar increase in p-ERK levels was observed after Dabrafenib treatment of HEK293T cells transfected singly with CRAF or co-transfected with CRAF and wt-BRAF. The ERKinhibitory inhibitory effect of Dabrafenib on G469S BRAF expressing cells was subtle.

Both classes of RAF inhibitors can induce phosphorylation of CRAF at serine 338 (S338), the regulatory phosphorylation site of CRAF protein $[18,38]$. We observed that Dabrafenib treatment of all HEK293T transfectants resulted in phosphorylation of the transfected CRAF molecule at S338, irrespective of the presence and type of BRAF molecule (Figure 2B).

\section{Inhibitory effect of Trametinib on mutant BRAF- induced ERK signaling}

A recent study revealed the superior efficacy of Trametinib versus several other MEK-inhibitors in cells with KRAS mutations and CRAF-mediated ERK pathway activation [39]. This effect may potentially privilege Trametinib in targeting cells harboring kinase-impaired BRAF mutations, as these mutations also activate the ERK pathway in a CRAF-dependent manner. Trametinib has previously shown efficacy in cells with V600E/K BRAF mutations in vitro and in the clinic. Therefore, we chose to test the effect of Trametinib in the context of mutant BRAF signaling.

We first evaluated whether Trametinib induces paradoxical ERK activation or phosphorylation of CRAF at S338, as was observed with Dabrafenib, in CRAFoverexpressing monotransfectants. Trametinib treatment did not result in either ERK activation or CRAF phosphorylation (Figure 2C). In addition, combined Dabrafenib and Trametinib treatment inhibited Dabrafenib-induced ERK activation in CRAF-overexpressing monotransfectants (Figure 2C). 


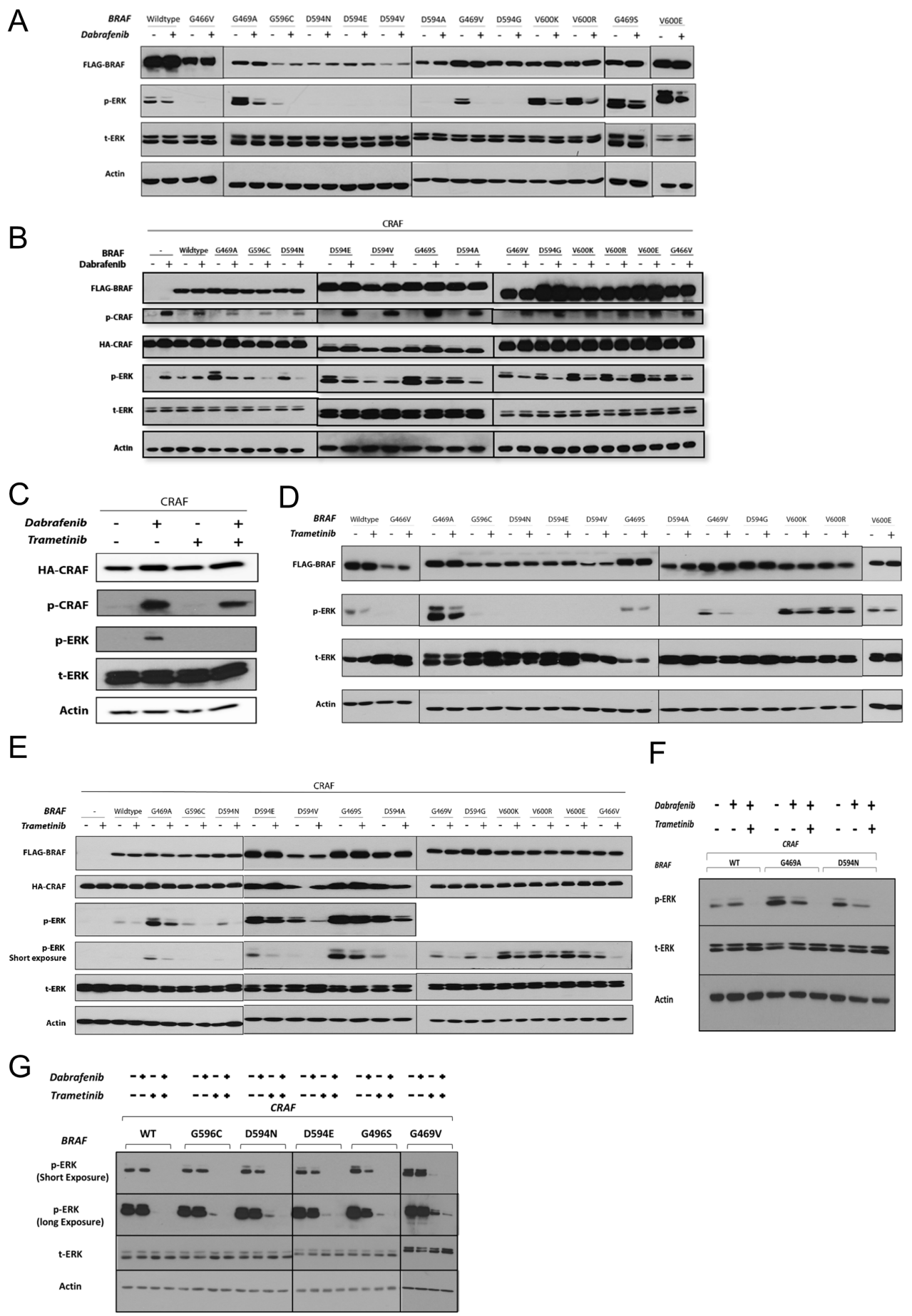

Figure 2: The effects of RAF and MEK inhibitors on non-V600 BRAF mutant-induced ERK signaling. A \& B. BRAF recombinant expression vectors were transfected singly (A) or co-transfected with CRAF (B) in HEK293T cells. After 48 h, cells were incubated for $2 \mathrm{~h}$ with the vehicle (DMSO) or Dabrafenib $(2.5 \mu \mathrm{M})$. Whole cell lysates were subjected to western blot analysis for the indicated proteins. C. 48 h post-CRAF mono-transfection, HEK293T cells were treated with Dabrafenib $(2.5 \mu \mathrm{M})$ in the presence or absence of Trametinib ( $25 \mathrm{nM}$ ) for $2 \mathrm{~h}$ (15 min Trametinib pre-treatment, 2 hr Trametinib monotherapy). D \& E. Same as in (A \& B) but treated with Trametinib $(25 \mathrm{nM})$. F. Combined Dabrafenib and Trametinib treatment of the representative non-V600 BRAF co-transfectants (as in C); note that combined treatment strongly enhances ERK inhibition. G. BEAS-2B cells were co-transfected with each of the 5 previously uncharacterized BRAF mutations and CRAF. 48h post-transfection cells were incubated in conjunction with monotherapy or combined treatment with Dabrafenib $(2.5 \mu \mathrm{M})$ and Trametinib $(25 \mathrm{nM})$ for $2 \mathrm{~h}$. Whole cell lysates were subjected to western blot analysis for the indicated proteins. 
Trametinib treatment of HEK293T cells singly expressing BRAF mutations conferring elevated kinase activity, or co-expressing them with CRAF, resulted in decreased p-ERK1/2 levels. The ERK-inhibitory effect of Trametinib on HEK293T cells expressing G469S-BRAF was weak (Figure 2, 2D \& 2E). Trametinib also decreased p-ERK levels in all the kinase-impaired BRAF/CRAF cotransfectants (Figure 2E).

Combinatorial Trametinib and Dabrafenib treatment enhances ERK inhibition in HEK293T and lung epithelial co-transfectants

To determine whether the combination of Trametinib and Dabrafenib enhances ERK inhibition, we investigated ERK inhibition by Dabrafenib in three representative co-transfectants (wt-BRAF/CRAF, G469A/ CRAF and D594N/CRAF) in the presence or absence of Trametinib (Figure 2F). In all co-transfectants, combined treatment significantly enhanced ERK inhibition compared with Dabrafenib monotherapy. In addition we tested the effect of Dabrafenib and/or Trametinib in lung epithelial cells (BEAS-2B) co-transfected with 5 previously uncharacterized BRAF mutations and CRAF (Figure $2 \mathrm{G})$. Dabrafenib monotherapy had only very weak ERK inhibitory effect. Trametinib single treatment caused strong ERK-inhibitory effect compared to Dabrafenib monotherapy whereas combinatorial treatment showed superior ERK-inhibitory effect compared to each of the single agents (Figure 2G). Combinatorial drug treatment also led to decreased viability in BEAS-2B cells stably transfected with two representative BRAF mutations (Supplementary Figure S2).

\section{Effect of Dabrafenib, Trametinib and their combination on non-V600 mutated BRAF human cancer cell lines}

The non-V600 BRAF mutations that we tested in our HEK293T and BEAS-2B model are all clustered, either in the P-loop (ATP-binding pocket) or in the DFG motif (a.a. 594-596 within the activation segment) of the BRAF kinase domain. Unfortunately, there is no available BRAF mutant NSCLC cell line harboring a mutation within the DFG motif. Therefore, we analyzed two NSCLC adenocarcinoma cell lines harboring two different mutations along the P-loop of the BRAF kinase domain and a CRC cell line of adenocarcinoma origin with a BRAF mutation positioned within the DFG motif.

H1395 and H1666 are NSCLC cells harboring a homozygous G469A BRAF mutation (high kinase) and a heterozygous G466V BRAF mutation (impaired kinase), respectively. $\mathrm{H} 508$ is a CRC (caecal) adenocarcinoma cell line harboring a heterozygous G596R BRAF mutation (impaired kinase).
Combinatorial Dabrafenib and Trametinib treatment enhances their anti-proliferative effects in non-V600 BRAF mutated cell lines

Non-V600 BRAF-mutated cell lines were exposed to single agent monotherapy and a combination of Dabrafenib and Trametinib, for three or five days depending on the cell line and then subjected to a CellTiter-Glo assay to quantify cell viability.

Trametinib monotherapy had a stronger antiproliferative effect than Dabrafenib on H1395 and H508 cells, while both monotherapies showed comparable antiproliferative effects in H1666 cells (Figure 3A).

In all tested cell lines, combinatorial treatment led to enhanced anti-proliferative effects compared to monotherapy treatments and the vehicle control. Interestingly, stronger growth inhibition was observed in kinase-impaired BRAF-harboring cells. Compared to the vehicle control, H508, H1666 and H1395 cells showed an $82 \pm 8.1 \%, 67 \pm 4.9 \%$ and $37 \pm 4.1 \%$ reduction in the number of viable cells, respectively, as a result of combined treatment with Dabrafenib and Trametinib.

To determine whether single or combined treatment triggered apoptosis, we measured caspase $3 / 7$ activation $72 \mathrm{~h}$ post drug treatment (caspase $3 / 7$ glo test). We did not detect significant caspase $3 / 7$ activation after $72 \mathrm{~h}$ of drug treatment in H1395 cells (Figure 3B). Upon single inhibitor monotherapy, increased caspase $3 / 7$ activity was observed only in H508 cells treated with Trametinib.

In cell lines with impaired kinase BRAF mutations (H1666 and H508), combinatorial therapy induced a 3and 4-fold increase, respectively, in caspase 3/7 activity compared with the vehicle control (Figure 3B).

Combination of Dabrafenib and Trametinib enhances and prolongs ERK inhibition in non-V600 BRAF mutated cell lines

We examined the acute and chronic effects of isolated and combined Dabrafenib and Trametinib treatment on the ERK pathway. In the given cell lines, we performed western- blot analysis on total lysates after $2 \mathrm{~h}$ and $48 \mathrm{~h}$ of drug treatment. All cell lines showed decreased p-ERK levels after $2 \mathrm{~h}$ of monotherapy treatment. Trametinib induced stronger ERK inhibition compared to Dabrafenib in all three cell lines. As expected, combined treatment caused the strongest ERK inhibition in all three cell lines (Figure 3C).

To determine whether combined treatment could overcome early adaptive insensitivity to Dabrafenib or Trametinib, we analyzed cell lysates $48 \mathrm{~h}$ post drug treatment. No rebound in p-ERK levels was detected in H1666 and H508 cells after 48 h of combined treatment, as opposed to treatment with single inhibitors. In H1395 cells after $48 \mathrm{~h}$ of combined treatment, a small increase in p-ERK levels was detected. 
A

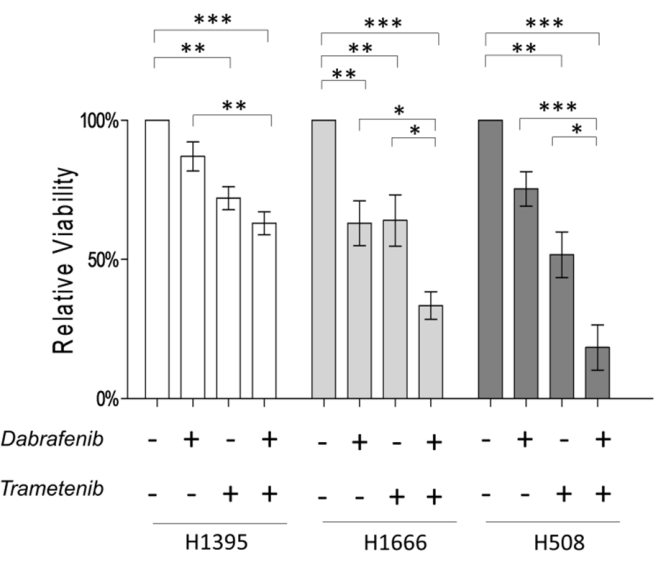

B

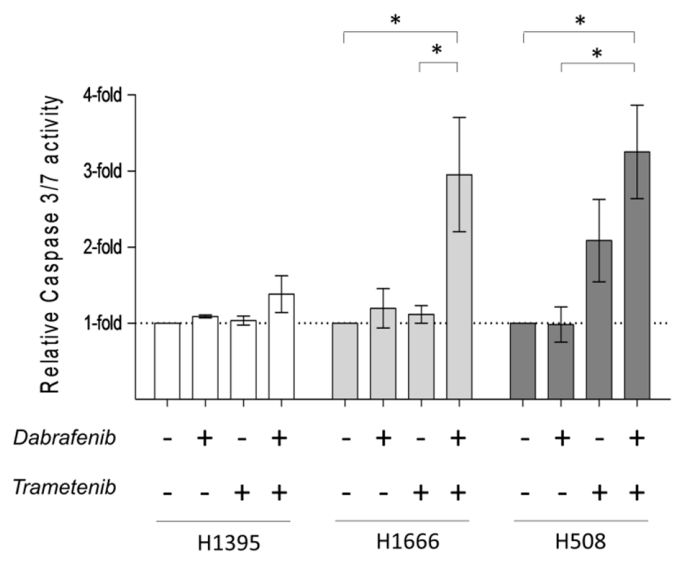

C

C
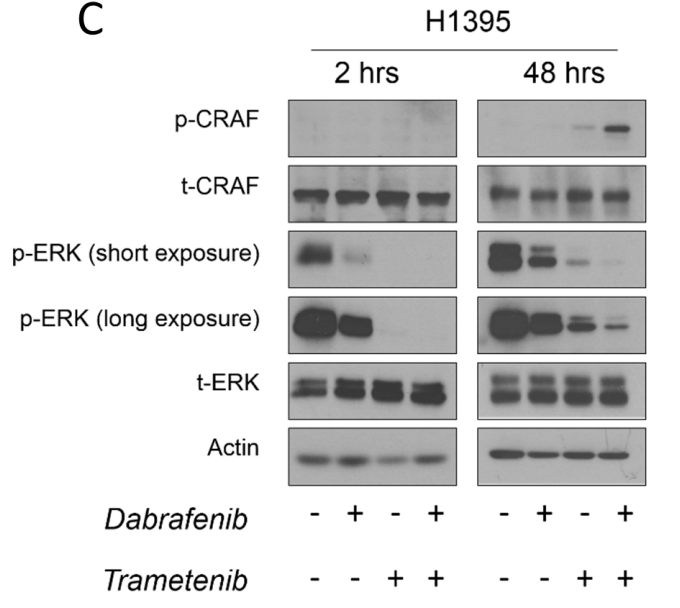

$\mathrm{H} 1395$
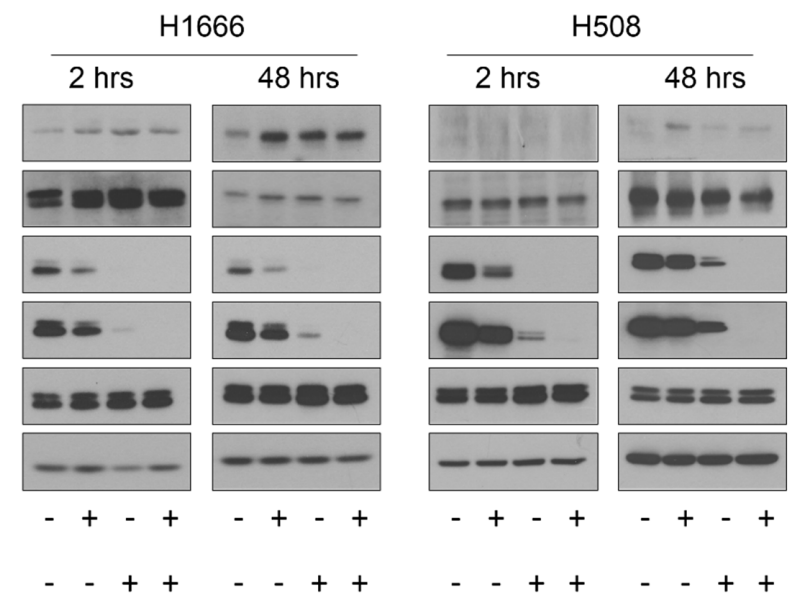

Figure 3: The effects of Dabrafenib, Trametinib and their combination on non-V600 BRAF mutated cell lines. A. Cells were incubated for 3 days (H1395 \& H1666) or 5 days (H508) with monotherapy or combined treatment with Dabrafenib (2.5 $\mu$ M) and Trametinib $(25 \mathrm{nM})$. Viability was measured, and relative viability was determined by normalizing to the vehicle group. Means \pm SEM are from at least three independent experiments, each performed in quadruplicate. B. Cells were incubated for 3 days with monotherapy or combined treatment with Dabrafenib $(2.5 \mu \mathrm{M})$ and Trametinib $(25 \mathrm{nM})$. Caspase-3/7 activity was measured and normalized to the number of viable cells. Values are displayed as fold increase compared to the vehicle group. Means \pm SEM are shown from at least three independent experiments, each performed in quadruplicate. C. Cells were incubated in conjunction with monotherapy or combined treatment with Dabrafenib $(2.5 \mu \mathrm{M})$ and Trametinib $(25 \mathrm{nM})$ for $2 \mathrm{~h}$ and $48 \mathrm{~h}$. Whole cell lysates were subjected to western blot analysis for the indicated proteins. $* \mathrm{p} \leq 0.05, * * \mathrm{p} \leq 0.01, * * * \mathrm{p} \leq 0.001$ 


\section{DISCUSSION}

In this study, we functionally analyzed a set of NSCLC-derived mutations clustered in exons 11 and 15 of the BRAF gene. These mutations were identified during routine diagnostic screening of a cohort of patients diagnosed and treated at our institution (seven mutations) or previously reported in the literature (six mutations). The seven mutations found at our institution were identified in a cohort of NSCLC patients preselected as having a limited or non-smoking history. Twelve out of the 229 NSCLC patients in the total cohort (5.2\%) harbored a BRAF mutation. In contrast to melanoma, only $25 \%$ of the BRAF mutant NSCLC cases carried a mutation that involved the valine residue at position 600. Similar observations have been previously reported in NSCLC [3-6]. However, to our knowledge, our cohort of BRAF mutant NSCLC patients exhibits the highest frequency of non-V600 BRAF mutations ever reported in NSCLC. These BRAF mutant NSCLCs did not harbor concomitant KRAS, NRAS, EGFR, ERBB2 or ALK mutations.

Characterization of the BRAF mutants G469S, G469V, D594E, D594N and G596C is, to our knowledge, unprecedented. In vitro kinase assays showed that D594E, D594N and G596C result in impaired kinase activity, similar to previously characterized mutations clustered along the DFG motif.

In contrast, G469S and G469V, both positioned along the P-loop, exhibited higher kinase activities compared to wt-BRAF. The kinase activity of G469S was comparable to that of V600E.

Observations made with the in vitro kinase assays were confirmed in a HEK293T cell model.

Cells transfected with BRAF mutants with elevated kinase activity had increased p-MEK and p-ERK levels compared to those transfected with wt-BRAF, while BRAF mutants with impaired kinase activity showed decreased levels of p-MEK and p-ERK.

Impaired kinase BRAF mutations are known to dimerize with CRAF and allosterically transactivate it, leading to ERK pathway activation [40]. Therefore, we evaluated the impact of various BRAF mutations on ERK signaling in the presence of CRAF. Co-expression of BRAF mutants with impaired kinase activity and CRAF strongly increased MEK and ERK phosphorylation. ERK activity in HEK293 cells co-expressing BRAF mutants with impaired kinase activity and CRAF was higher compared to that in wt-BRAF/CRAF co-transfectants. The only exception was the D594V BRAF mutant, as its co-expression with CRAF resulted in a modest increase in MEK and ERK activity. This result was consistent with that of a previous report in another cellular model [9]. These results suggest that D594V BRAF may be a non-pathogenic variant or a kinase-independent oncogene. While the role of CRAF in NSCLC has not been fully elucidated, CRAF overexpression has been reported in a large subset of lung cancers $[8,41,42]$. In a transgenic mouse model, lung-targeted overexpression of CRAF can induce development of NSCLC [43]. In cancers with KRAS mutations, CRAF plays a pivotal role in ERK signaling and in the early stages of oncogenesis [44, 45]. CRAF knockdown has been shown to inhibit growth of NSCLC cells harboring BRAF mutations conferring impaired kinase activity [10].

A clinically relevant dose of Dabrafenib, a type I RAF-inhibitor, in HEK293T cells reduced ERK activity induced by BRAF mutations conferring high kinase activity in the presence and absence of CRAF. Furthermore, Dabrafenib also inhibited ERK activity induced by BRAF mutants conferring impaired kinase activity co-expressed with CRAF. The only exception was once again the D594V BRAF/CRAF co-transfectant, which showed increased ERK activity upon Dabrafenib treatment (similar to wt-BRAF/CRAF). When RAFs are in an inactive state, RAF inhibitors can induce dimerization of inhibitor-bound RAF with inhibitor-free RAF causing its transactivation and hyperactivation, ultimately leading to ERK pathway activation [19]. As we observed, D594V BRAF, even in the presence of CRAF, did not induce strong ERK activity. This result indicates that RAF isoforms remain inactive in the presence of the D594V BRAF. Therefore, pathway activation upon Dabrafenib treatment may be explained by the opposing mode of action of Dabrafenib towards the inactive fraction of RAF isoforms.

Dabrafenib-induced paradoxical ERK activation was observed in cells singly expressing exogenous CRAF, as well as in cells co-expressing exogenous wt-BRAF and CRAF. This result is consistent with reports on the CRAF dependence of paradoxical ERK activation induced by RAF inhibitors. [17-19, 46].

Unlike Dabrafenib, the MEK-inhibitor Trametinib did not induce ERK activation in CRAF monotransfectants. In HEK293T cells, Trametinib modestly decreased ERK activity induced by BRAF mutations conferring elevated kinase activity while strongly inhibited kinase-impaired BRAF/CRAF-induced ERK activation. Moreover, we showed that combinatorial treatment with Trametinib and Dabrafenib overcame paradoxical ERK activation in wt-BRAF/CRAF HEK293T and lung epithelial co-transfectants and substantially improved ERK inhibition in non-V600 BRAF mutants with both impaired and elevated kinase activity.

Serine-338 is a regulatory site in the N-region of CRAF whose phosphorylation is believed to be a preliminary step for CRAF activation. However, the exact mechanism and full sequence of events prior and subsequent to CRAF activation remain largely unknown $[47,48]$. Both classes of RAF-inhibitors have been shown to induce phosphorylation of CRAF at S338 [18, 19]. We also observed the similar phenomenon with Dabrafenib. 
Notably, activated CRAF is suggested to be associated with several kinase-independent functions related to oncogenesis [49-53]. Therefore, it has yet to be determined whether over time activated CRAF can contribute to kinase-independent resistance mechanisms to RAF inhibitors in BRAF mutated cancers [54].

Using our mutant BRAF/CRAF co-expressing HEK293T model and lung epithelial cells, we demonstrated that non-V600 BRAF mutations, including kinase-impaired mutations, are "druggable".

To evaluate whether these results could be confirmed in human cancer cell lines, we tested the effects of Dabrafenib, Trametinib and their combination on cell lines harboring BRAF mutations located at positions other than V600, which were representative of distinctive positions along the BRAF kinase domain. As there is no NSCLC cell line with a BRAF mutation in the DFG motif, we included a CRC cell line of adenocarcinoma origin harboring a BRAF mutation along this motif, although we are aware that the significance of BRAF mutations and their inhibition might be context dependent. Concerning the five mutations of which the characterization is unprecedented, in the future the availability of patientderived NSCLC cell lines harboring these BRAF mutations would help broaden our knowledge regarding mechanism of oncogenesis and drug response.

The combination of Dabrafenib and Trametinib resulted in enhanced growth inhibition compared to monotherapy treatments in the three tested cell lines.

Combined treatment resulted in significantly enhanced caspase 3/7 activity in $\mathrm{H} 1666$ and $\mathrm{H} 508$ cells but not in the H1395 cell line. This observation is consistent with a previous report on a different MEK inhibitor (PD0325901) that inhibits H1395 cell growth without inducing apoptosis [55]. However, in previous studies, another NSCLC-derived cell line harboring the same BRAF mutation (G469A) showed both growth inhibition and apoptosis upon MEK inhibition [55, 56]. Therefore, this lack of apoptosis induction by MEK inhibitors in H1395 cells seems to be related to unknown cellular or genetic factors, while a potential therapeutic benefit might still be derived from the growth inhibition.

In all the tested cell lines, combined treatment enhanced and prolonged ERK inhibition compared to monotherapy treatment (48 h). As in V600-mutated cells, this result suggests that combined RAF and MEK targeting can overcome the early adaptive insensitivity to RAF inhibitor monotherapy in non-V600 BRAF mutated cells.

Interestingly, $\mathrm{H} 1666$ and $\mathrm{H} 508$ cell lines were previously shown to be resistant - or poorly responsiveto the selective RAF-inhibitor Vemurafenib, as well as to the MEK inhibitor Selumetinib [57-60]. As ERK activation in the given cell lines is CRAF-mediated, the fact that Vemurafenib is a weak CRAF inhibitor may contribute to the differential responses. Notably, CRAF knockdown has been shown to inhibit growth of H1666 cells [10].
A recent study investigated the differential efficacy of MEK inhibitors in KRAS-mutated cancer cells in which ERK pathway activation is supposed to be CRAFmediated. The study reveals that two MEK inhibitors (Selumetinib and PD0325901) are less efficient than Trametinib for sustained suppression of CRAF-mediated ERK activity. This result may explain why H1666 and H508 cells are more sensitive to Trametinib than to Selumetinib, as BRAF mutations in these cell lines activate the ERK pathway in a CRAF-dependent manner, similarly to KRAS-mutated cells. In contrast, H1666 was previously reported to be sensitive to PD0325901, which is mechanistically similar to Selumetinib, by means of making inhibited MEK prone to reactivation by CRAF [39, 61]. Therefore, further investigation of the comparative efficacy of various MEK inhibitors in BRAF-mutated cancers would help to explain these contradicting results.

Due to the small size of our patient cohort, we could not detect any significant clinical differences between BRAF mutated and other molecular subtypes of lung cancer or between different BRAF mutation types.

In conclusion, our findings confirm that non-V600 BRAF mutations are not rare in NSCLC. We demonstrate that non-V600 BRAF mutations, resulting in either high or impaired kinase activity, confer sensitivity to combined Dabrafenib and Trametinib treatment. Dabrafenib monotherapy has only a weak effect, and targeting impaired-kinase BRAF mutations or CRAFoverexpressing cells with Dabrafenib alone may even lead to paradoxical ERK activation. Notably, the sensitivity of cells with mutations conferring impaired kinase activity to combinatorial Dabrafenib and Trametinib treatment has not previously been described. Our findings support the clinical exploration of the efficacy of combined DabrafenibTrametinib treatment in advanced NSCLC patients harboring non-V600 BRAF mutations in their tumors.

\section{MATERIALS AND METHODS}

\section{Patient cohort}

Patients with locally advanced or metastatic (stage IIIB or stage IV) adenocarcinoma of the lung and a non- or limited-smoking history were included in the study.

Prospectively collected data included age at diagnosis, gender, smoking history, ethnicity, Karnofsky performance status scale (KPSS), treatments and survival time.

\section{Diagnostics and mutation analysis}

DNA was isolated from formalin fixed paraffin embedded (FFPE) tumor samples (Qiagen 56404). The presence of EGFR, ERBB2, KRAS, NRAS, HRAS and BRAF mutations was tested using denaturing gradient gel electrophoresis [62] or next generation sequencing-based methods. 


\section{DNA constructs}

A full-length BRAF cDNA-bearing cassette was a kind gift from Loredana Vecchione in Prof. Sabine Tejpar's lab (Catholic University Leuven). The BRAF coding sequence was PCR-cloned (AccuPrime, Life Technologies, 12344-024) into the desired destination vector, PX3FLAG-CMV-14 (Sigma, E7908). An empty vector (puno1-hRAF1) and HA-tagged-CRAF expression vector (customized) were obtained from InvivoGen (Toulouse, France).

\section{Site-directed mutagenesis}

Desired mutations were introduced in the BRAF coding sequence using site-directed mutagenesis (GeneArt Site-Directed Mutagenesis System, Life-Technologies, A13312). The full length BRAF coding sequence and the insertion sites in the expression vector were fully sequenced for each construct generated.

\section{Cell culture and transfections}

HEK293T cells were a kind gift from Ron Kooijman (FARC, Vrije Universiteit Brussel). Cells were cultured in Dulbecco's Modified Eagles Medium (DMEM) (Life Technologies, 31966-047) supplemented with 10\% fetal bovine serum (FBS) (Perbio Science, SV30160.03) and penicillin-streptomycin (pen-strep) (Life Technologies, 15140-148). Cells were passaged every three days.

Prior to transfection, 150,000 cells/well were seeded in 24-well plates and incubated overnight (in antibiotic-free medium). The following day, the medium was changed to OptiMEM (Life Technologies 31985047) and retained in the incubator for 30 minutes. Transfections and co-transfections were performed using Lipofectamine-2000 (116680-19) according to the manufacturer's instructions. Six hours post-transfection, OptiMEM was changed to antibiotic-free DMEM (supplemented with 10\% FBS). Cells were collected $48 \mathrm{~h}$ post-transfection for western blot analysis.

BEAS-2B cells were kind gift from Prof. Didier Cataldo (University of liége) and were cultured in DMEM supplemented with 10\% (FBS) and pen-strep. BEAS-2B cells were transfected as described for HEK293T cells, due to increased toxicity the amount of DNA transfected was reduced to $0.4 \mu \mathrm{g}$.

Stably transfected BEAS-2B lines were generated by reseeding the transiently transfected cells (after $48 \mathrm{~h}$ ) in presence of corresponding antibiotics for 2-3 weeks. Cells transfected with BRAF expression cassettes or PX3FLAGCMV-14 vector were selected in medium supplemented with $750 \mu \mathrm{g} / \mathrm{ml} \mathrm{G418} \mathrm{(sigma-aldrich),} \mathrm{and} \mathrm{cells} \mathrm{co-}$ transfected (in two steps) with CRAF expression cassette or puno1-hRAF1 were selected in medium supplemented with $750 \mu \mathrm{g} / \mathrm{ml} \mathrm{G} 418$ and $5 \mu \mathrm{g} / \mathrm{ml}$ Blasticidin (invivogen).
H1395, H1666 and H508 cells were obtained from ATCC. H1395 and H508 were cultured in RMPI-1640 (ATCC: 30-2001) supplemented with 10\% FBS and pen-strep. For H1666 cells, F12-based (ATCC: 30-2006) ACL-4 medium was freshly prepared following ATCC's recommendations. All cells were periodically tested for mycoplasma.

\section{In vitro kinase assay}

BRAF proteins were transiently expressed in HEK293T cells and subsequently purified using a flagimmunoprecipitation kit (Sigma, FLAGIPT1). Equivalent amounts of BRAF proteins were subjected to a kinase reaction together with kinase-dead MEK1 substrate (100 ng BRAF kinase +500 ng inactive MEK1, as recommended by Merck Millipore, 14-420) in the presence of $10 \mathrm{mM}$ ATP (Ultra Pure ATP, Promega) at $30^{\circ} \mathrm{C}$. Kinase reactions were terminated after 30 minutes, and reaction solutions were visualized by chemiluminescence using antiphospho-MEK and anti-Flag antibodies. ImageJ software (http://imagej.nih.gov/ij/) was used to quantify p-MEK and flag-BRAF levels. p-MEK levels were normalized to the related Flag-BRAF levels. Fold increase over wtBRAF was calculated and reported.

\section{Western blot}

Cells were lysed in $1 \%$ triton-X buffer supplemented with phosphatase, protease inhibitor (Sigma, P8340 and P5726) and leupeptin trifluoroacetate (Sigma, L2023).

Lysates were centrifuged, and protein concentration was determined using the Bradford protein assay kit (BioRad). Equivalent amounts of protein were loaded on a $10 \%$ resolving acrylamide gel. Protein transfer was conducted overnight at $4^{\circ} \mathrm{C}$ using polyvinylidene fluoride membranes (PVDF). The membranes were blocked with $5 \%$ nonfat milk and washed. Blocked membranes were labeled with primary antibody overnight at $4^{\circ} \mathrm{C}$ followed by $1 \mathrm{~h}$ incubation with the corresponding secondary horseradish peroxidase (HRP)-conjugated antibody at $37^{\circ} \mathrm{C}$. Detection was performed using enhanced chemiluminescence (ECL) detection reagent (Isogen Life Science, K-12045-D20) and Fuji super films (104253) or by ImageQuant LAS-4000 (GE Healthcare). Western blot antibodies were: phosphoMEK1/2 (cell signaling, 9121), total-MEK1/2 (cell signaling, 9122), phospho-ERK1/2 (cell signaling, 4370), total ERK1/2 (cell signaling, 4695), phospho-S338-CRAF (cell signaling, 9427), HA-TAG (cell signaling, 2367), FLAG (Sigma, F1804), and anti-beta ACTIN ( Sigma, A1978).

\section{Inhibitors}

Dabrafenib (TAFINLAR) was provided by GlaxoSmithKline. Trametinib (GSK1120212) was obtained from selleckchem (S2673). 


\section{Cell viability and caspase $3 / 7$ activity assays}

Viability was determined using a CellTiter-Glo Luminescent kit (Promega: G7570). Caspase 3/7 activity was determined with a Caspase-Glo 3/7 Assay Kit (Promega; G8091), as previously described [63]. Briefly, for both assays, cells were seeded in 384-well plates at 800-2,500 cells/well. The following day, drugs were added (with equal amounts of dimethyl sulfoxide (DMSO) for all conditions) and incubated until the designated time points for each assay. Caspase activities were measured and normalized to the number of viable cells from the corresponding wells in the same plates.

\section{Statistical methods}

Fisher's exact test was used to compare the gender and smoking history between V600 and non-V600 patients as well as between patients with BRAF containing mutations conferring high and impaired kinase activity. A Mann-Whitney U test was used to compare age at diagnosis between the given groups. Overall survival was estimated using the Kaplan-Meier method, and the curves were compared using log-rank tests. For proliferation and caspase 3/7 data, means of at least 3 independent experiments, each performed in quadruplicate, were compared by a one-way Anova, post-hoc test. SPSS was used for statistical analysis and generation of the Kaplan-Meier curves.

\section{ACKNOWLEDGMENTS}

Our gratitude to Hugo Vandenplas for his technical assistance. Special thanks to $\mathrm{M}$. Goossens and $\mathrm{M}$. Noparast for their data analysis expertise and advices.

\section{CONFLICTS OF INTEREST}

Authors claim no conflicts of interest

\section{FUNDING}

The work was funded by the Cancer Plan 29-39 Belgium and by the Wetenschappelijk Fonds Willy Gepts of the UZ Brussel, Vrije Universiteit Brussel.

\section{Author contributions}

A.N.: designed the experiments, generated the BRAF expression vectors, generated and analyzed the data, generated and assembled tables and figures and wrote the manuscript. E.T.: designed and supervised the study experiments and participated in manuscript writing and approval. P.G.: participated in the experimental work, data analysis and generation of the figures and reviewed the manuscript. G.V.: clinical data collection, clinical data analysis and generation of the figures and tables, reviewed the manuscript. S.D.B.: performed the mutation analysis on the clinical samples, contributed during the set-up of the cell work. L.D.: collected the clinical data and reviewed the manuscript. J.D.G.: Supervised and participated in the study design, clinical data collection and writing and approval of the manuscript.

\section{Data and materials availability}

All raw data and the materials used in this study are available upon request.

\section{REFERENCES}

1. Holderfield M, Deuker MM, McCormick F, McMahon M. Targeting RAF kinases for cancer therapy: BRAF-mutated melanoma and beyond. Nat Rev Cancer. 2014; 14:455-67. https://doi.org/10.1038/nrc3760.

2. Lin L, Asthana S, Chan E, Bandyopadhyay S, Martins MM, Olivas V, Yan JJ, Pham L, Wang MM, Bollag G, Solit DB, Collisson EA, Rudin CM, et al. Mapping the molecular determinants of BRAF oncogene dependence in human lung cancer. Proc Natl Acad Sci USA. 2014; 111:E748-57. https://doi.org/10.1073/pnas.1320956111.

3. Marchetti A, Felicioni L, Malatesta S, Grazia Sciarrotta M, Guetti L, Chella A, Viola P, Pullara C, Mucilli F, Buttitta F. Clinical features and outcome of patients with non-small-cell lung cancer harboring BRAF mutations. J Clin Oncol. 2011; 29:3574-79. https://doi.org/10.1200/JCO.2011.35.9638.

4. Litvak AM, Paik PK, Woo KM, Sima CS, Hellmann MD, Arcila ME, Ladanyi M, Rudin CM, Kris MG, Riely GJ. Clinical characteristics and course of 63 patients with BRAF mutant lung cancers. J Thorac Oncol. 2014; 9:166974. https://doi.org/10.1097/JTO.0000000000000344.

5. Kinno T, Tsuta K, Shiraishi K, Mizukami T, Suzuki M, Yoshida A, Suzuki K, Asamura H, Furuta K, Kohno T, Kushima R. Clinicopathological features of nonsmall cell lung carcinomas with BRAF mutations. Ann Oncol. 2014; 25:138-42. https://doi.org/10.1093/annonc/mdt495.

6. Cardarella S, Ogino A, Nishino M, Butaney M, Shen J, Lydon C, Yeap BY, Sholl LM, Johnson BE, Jänne PA. Clinical, pathologic, and biologic features associated with BRAF mutations in non-small cell lung cancer. Clin Cancer Res. 2013; 19:4532-40. https://doi.org/10.1158/1078-0432. CCR-13-0657.

7. Imielinski M, Berger AH, Hammerman PS, Hernandez B, Pugh TJ, Hodis E, Cho J, Suh J, Capelletti M, Sivachenko A, Sougnez C, Auclair D, Lawrence MS, et al. Mapping the hallmarks of lung adenocarcinoma with massively parallel sequencing. Cell. 2012; 150:1107-20. https://doi. org/10.1016/j.cell.2012.08.029.

8. Niault TS, Baccarini M. Targets of Raf in tumorigenesis. Carcinogenesis. 2010; 31:1165-74. https://doi.org/10.1093/ carcin/bgp337.

9. Wan PT, Garnett MJ, Roe SM, Lee S, Niculescu-Duvaz D, Good VM, Jones CM, Marshall CJ, Springer CJ, Barford D, Marais R, and Cancer Genome Project. Mechanism of 
activation of the RAF-ERK signaling pathway by oncogenic mutations of B-RAF. Cell. 2004; 116:855-67. https://doi. org/10.1016/S0092-8674(04)00215-6.

10. Sen B, Peng S, Tang X, Erickson HS, Galindo H, Mazumdar T, Stewart DJ, Wistuba I, Johnson FM. Kinaseimpaired BRAF mutations in lung cancer confer sensitivity to dasatinib. Sci Transl Med. 2012; 4:136ra70. https://doi. org/10.1126/scitranslmed.3003513.

11. Heidorn SJ, Milagre C, Whittaker S, Nourry A, NiculescuDuvas I, Dhomen N, Hussain J, Reis-Filho JS, Springer CJ, Pritchard C, Marais R. Kinase-dead BRAF and oncogenic RAS cooperate to drive tumor progression through CRAF. Cell. 2010; 140:209-21. https://doi.org/10.1016/j. cell.2009.12.040.

12. Solit DB, Garraway LA, Pratilas CA, Sawai A, Getz G, Basso A, Ye Q, Lobo JM, She Y, Osman I, Golub TR, Sebolt-Leopold J, Sellers WR, Rosen N. BRAF mutation predicts sensitivity to MEK inhibition. Nature. 2006; 439:358-62. https://doi.org/10.1038/nature04304.

13. Kamata T, Hussain J, Giblett S, Hayward R, Marais R, Pritchard C. BRAF inactivation drives aneuploidy by deregulating CRAF. Cancer Res. 2010; 70:8475-86. https:// doi.org/10.1158/0008-5472.CAN-10-0603.

14. Khazak V, Astsaturov I, Serebriiskii IG, Golemis EA. Selective Raf inhibition in cancer therapy. Expert Opin Ther Targets. 2007; 11:1587-609. https://doi.org/10.1517/14728 222.11.12.1587.

15. Greger JG, Eastman SD, Zhang V, Bleam MR, Hughes AM, Smitheman KN, Dickerson SH, Laquerre SG, Liu L, Gilmer TM. Combinations of BRAF, MEK, and PI3K/mTOR inhibitors overcome acquired resistance to the BRAF inhibitor GSK2118436 dabrafenib, mediated by NRAS or MEK mutations. Mol Cancer Ther. 2012; 11:909-20. https://doi.org/10.1158/1535-7163.MCT-11-0989.

16. Bollag G, Hirth P, Tsai J, Zhang J, Ibrahim PN, Cho H, Spevak W, Zhang C, Zhang Y, Habets G, Burton EA, Wong B, Tsang G, et al. Clinical efficacy of a RAF inhibitor needs broad target blockade in BRAF-mutant melanoma. Nature. 2010; 467:596-99. https://doi.org/10.1038/nature09454.

17. Holderfield M, Nagel TE, Stuart DD. Mechanism and consequences of RAF kinase activation by small-molecule inhibitors. Br J Cancer. 2014; 111:640-45. https://doi. org/10.1038/bjc.2014.139.

18. Hatzivassiliou G, Song K, Yen I, Brandhuber BJ, Anderson DJ, Alvarado R, Ludlam MJ, Stokoe D, Gloor SL, Vigers G, Morales T, Aliagas I, Liu B, et al. RAF inhibitors prime wild-type RAF to activate the MAPK pathway and enhance growth. Nature. 2010; 464:431-35. https://doi.org/10.1038/ nature08833.

19. Poulikakos PI, Zhang C, Bollag G, Shokat KM, Rosen N. RAF inhibitors transactivate RAF dimers and ERK signalling in cells with wild-type BRAF. Nature. 2010; 464:427-30. https://doi.org/10.1038/nature08902.

20. Holderfield M, Merritt H, Chan J, Wallroth M, Tandeske L, Zhai H, Tellew J, Hardy S, Hekmat-Nejad M,
Stuart DD, McCormick F, Nagel TE. RAF inhibitors activate the MAPK pathway by relieving inhibitory autophosphorylation. Cancer Cell. 2013; 23:594-602. https://doi.org/10.1016/j.ccr.2013.03.033.

21. Spagnolo F, Ghiorzo P, Queirolo P. Overcoming resistance to BRAF inhibition in BRAF-mutated metastatic melanoma. Oncotarget. 2014; 5:10206-21. https://doi.org/10.18632/ oncotarget.2602.

22. Sun C, Wang L, Huang S, Heynen GJ, Prahallad A, Robert C, Haanen J, Blank C, Wesseling J, Willems SM, Zecchin D, Hobor S, Bajpe PK, et al. Reversible and adaptive resistance to BRAF(V600E) inhibition in melanoma. Nature. 2014; 508:118-22. https://doi.org/10.1038/nature13121.

23. Lito P, Rosen N, Solit DB. Tumor adaptation and resistance to RAF inhibitors. Nat Med. 2013; 19:1401-09. https://doi. org/10.1038/nm.3392.

24. Lito P, Pratilas CA, Joseph EW, Tadi M, Halilovic E, Zubrowski M, Huang A, Wong WL, Callahan MK, Merghoub T, Wolchok JD, de Stanchina E, Chandarlapaty $\mathrm{S}$, et al. Relief of profound feedback inhibition of mitogenic signaling by RAF inhibitors attenuates their activity in BRAFV600E melanomas. Cancer Cell. 2012; 22:668-82. https://doi.org/10.1016/j.ccr.2012.10.009.

25. Corcoran RB, Ebi H, Turke AB, Coffee EM, Nishino M, Cogdill AP, Brown RD, Della Pelle P, Dias-Santagata D, Hung KE, Flaherty KT, Piris A, Wargo JA, et al. EGFRmediated re-activation of MAPK signaling contributes to insensitivity of BRAF mutant colorectal cancers to RAF inhibition with vemurafenib. Cancer Discov. 2012; 2:22735. https://doi.org/10.1158/2159-8290.CD-11-0341.

26. Montagut C, Sharma SV, Shioda T, McDermott U, Ulman M, Ulkus LE, Dias-Santagata D, Stubbs H, Lee DY, Singh A, Drew L, Haber DA, Settleman J. Elevated CRAF as a potential mechanism of acquired resistance to BRAF inhibition in melanoma. Cancer Res. 2008; 68:4853-61. https://doi.org/10.1158/0008-5472.CAN-07-6787.

27. Gray ES, Rizos H, Reid AL, Boyd SC, Pereira MR, Lo J, Tembe V, Freeman J, Lee JH, Scolyer RA, Siew K, Lomma C, Cooper A, et al. Circulating tumor DNA to monitor treatment response and detect acquired resistance in patients with metastatic melanoma. Oncotarget. 2015; 6:42008-18. https://doi.org/10.18632/oncotarget.5788.

28. Fedorenko IV, Gibney GT, Sondak VK, Smalley KS. Beyond BRAF: where next for melanoma therapy? $\mathrm{Br}$ J Cancer. 2015; 112:217-26. https://doi.org/10.1038/ bjc.2014.476.

29. Long GV, Stroyakovskiy D, Gogas H, Levchenko E, de Braud F, Larkin J, Garbe C, Jouary T, Hauschild A, Grob JJ, Chiarion-Sileni V, Lebbe C, Mandalà M, et al. Dabrafenib and trametinib versus dabrafenib and placebo for Val600 BRAF-mutant melanoma: a multicentre, double-blind, phase 3 randomised controlled trial. Lancet. 2015; 386:44451. https://doi.org/10.1016/S0140-6736(15)60898-4.

30. Miller MA, Oudin MJ, Sullivan RJ, Wang SJ, Meyer AS, Im H, Frederick DT, Tadros J, Griffith LG, Lee H, Weissleder 
R, Flaherty KT, Gertler FB, Lauffenburger DA. Reduced Proteolytic Shedding of Receptor Tyrosine Kinases Is a Post-Translational Mechanism of Kinase Inhibitor Resistance. Cancer Discov. 2016; 6:382-99. https://doi. org/10.1158/2159-8290.CD-15-0933.

31. Robert C, Karaszewska B, Schachter J, Rutkowski P, Mackiewicz A, Stroiakovski D, Lichinitser M, Dummer R, Grange F, Mortier L, Chiarion-Sileni V, Drucis K, Krajsova I, et al. Improved overall survival in melanoma with combined dabrafenib and trametinib. N Engl J Med. 2015; 372:30-39. https://doi.org/10.1056/NEJMoa1412690.

32. Villanueva J, Vultur A, Herlyn M. Resistance to BRAF inhibitors: unraveling mechanisms and future treatment options. Cancer Res. 2011; 71:7137-40. https://doi. org/10.1158/0008-5472.CAN-11-1243.

33. Hu-Lieskovan S, Mok S, Homet Moreno B, Tsoi J, Robert L, Goedert L, Pinheiro EM, Koya RC, Graeber TG, Comin-Anduix B, Ribas A. Improved antitumor activity of immunotherapy with BRAF and MEK inhibitors in BRAF(V600E) melanoma. Sci Transl Med. 2015; 7:279ra41. https://doi.org/10.1126/scitranslmed.aaa4691.

34. Planchard D. Interim results of a phase 2 study of the BRAF inhibitor (BRAFi) dabrafenib (D) in combination with the MEK inhibitor trametinib ( $\mathrm{T}$ ) in patients (pts) with BRAF V600E mutated (mut) metastatic non-small cell lung cancer (NSCLC). American Society of Clinical Oncology (ASCO) Annual Meeting, Chicago, IL, USA. 2015; Abstract \#8006.

35. Atreya CE. Updated efficacy of the MEK inhibitor trametinib (T), BRAF inhibitor dabrafenib (D), and antiEGFR antibody panitumumab (P) in patients (pts) with BRAF V600E mutated (BRAFm) metastatic colorectal cancer (mCRC). 2015 ASCO Annual Meeting. 2015; Abstract Number: 103.

36. Willmore-Payne C, Holden JA, Tripp S, Layfield LJ. Human malignant melanoma: detection of BRAF- and c-kit-activating mutations by high-resolution amplicon melting analysis. Hum Pathol. 2005; 36:486-93. https://doi. org/10.1016/j.humpath.2005.03.015

37. Agency EM. Tafinlar, summary of product characteristics. European Medicines Agency. 2013.

38. Hu J, Stites EC, Yu H, Germino EA, Meharena HS, Stork PJ, Kornev AP, Taylor SS, Shaw AS. Allosteric activation of functionally asymmetric RAF kinase dimers. Cell. 2013; 154:1036-46. https://doi.org/10.1016/j.cell.2013.07.046.

39. Lito P, Saborowski A, Yue J, Solomon M, Joseph E, Gadal S, Saborowski M, Kastenhuber E, Fellmann C, Ohara K, Morikami K, Miura T, Lukacs C, et al. Disruption of CRAFmediated MEK activation is required for effective MEK inhibition in KRAS mutant tumors. Cancer Cell. 2014; 25:697-710. https://doi.org/10.1016/j.ccr.2014.03.011.

40. Lavoie H, Therrien M. Regulation of RAF protein kinases in ERK signalling. Nat Rev Mol Cell Biol. 2015; 16:28198. https://doi.org/10.1038/nrm3979.

41. Qiu ZX, Wang L, Han J, Liu D, Huang W, Altaf K, Qiu XS, Javed MA, Zheng J, Chen BJ, Li WM. Prognostic impact of Raf-1 and p-Raf-1 expressions for poor survival rate in non-small cell lung cancer. Cancer Sci. 2012; 103:1774-79. https://doi.org/10.1111/j.1349-7006.2012.02375.x.

42. Cekanova M, Majidy M, Masi T, Al-Wadei HA, Schuller HM. Overexpressed Raf-1 and phosphorylated cyclic adenosine 3'-5'-monophosphatate response element-binding protein are early markers for lung adenocarcinoma. Cancer. 2007; 109:1164-73. https://doi.org/10.1002/cncr.22520.

43. Fedorov LM, Papadopoulos T, Tyrsin OY, Twardzik T, Götz $\mathrm{R}$, Rapp UR. Loss of p53 in craf-induced transgenic lung adenoma leads to tumor acceleration and phenotypic switch. Cancer Res. 2003; 63:2268-77.

44. Karreth FA, Frese KK, DeNicola GM, Baccarini M, Tuveson DA. C-Raf is required for the initiation of lung cancer by K-Ras(G12D). Cancer Discov. 2011; 1:128-36. https://doi.org/10.1158/2159-8290.CD-10-0044.

45. Blasco RB, Francoz S, Santamaría D, Cañamero M, Dubus P, Charron J, Baccarini M, Barbacid M. c-Raf, but not $\mathrm{B}$-Raf, is essential for development of K-Ras oncogenedriven non-small cell lung carcinoma. Cancer Cell. 2011; 19:652-63. https://doi.org/10.1016/j.ccr.2011.04.002.

46. Freeman AK, Ritt DA, Morrison DK. Effects of Raf dimerization and its inhibition on normal and diseaseassociated Raf signaling. Mol Cell. 2013; 49:751-58. https://doi.org/10.1016/j.molcel.2012.12.018.

47. Zang M, Gong J, Luo L, Zhou J, Xiang X, Huang W, Huang Q, Luo X, Olbrot M, Peng Y, Chen C, Luo Z. Characterization of Ser338 phosphorylation for Raf-1 activation. J Biol Chem. 2008; 283:31429-37. https://doi. org/10.1074/jbc.M802855200.

48. Shin SY, Rath O, Choo SM, Fee F, McFerran B, Kolch W, Cho KH. Positive- and negative-feedback regulations coordinate the dynamic behavior of the Ras-Raf-MEK-ERK signal transduction pathway. J Cell Sci. 2009; 122:425-35. https://doi.org/10.1242/jcs.036319.

49. Chen J, Fujii K, Zhang L, Roberts T, Fu H. Raf-1 promotes cell survival by antagonizing apoptosis signal-regulating kinase 1 through a MEK-ERK independent mechanism. Proc Natl Acad Sci USA. 2001; 98:7783-88. https://doi. org/10.1073/pnas.141224398.

50. Maurer G, Tarkowski B, Baccarini M. Raf kinases in cancer-roles and therapeutic opportunities. Oncogene. 2011; 30:3477-88. https://doi.org/10.1038/onc.2011.160.

51. Mielgo A, Seguin L, Huang M, Camargo MF, Anand S, Franovic A, Weis SM, Advani SJ, Murphy EA, Cheresh DA. A MEK-independent role for CRAF in mitosis and tumor progression. Nat Med. 2011; 17:1641-45. https://doi. org/10.1038/nm.2464.

52. Wang HG, Reed JC. Bc1-2, Raf-1 and mitochondrial regulation of apoptosis. Biofactors. 1998; 8:13-16. https:// doi.org/10.1002/biof.5520080103.

53. Smalley KS, Xiao M, Villanueva J, Nguyen TK, Flaherty KT, Letrero R, Van Belle P, Elder DE, Wang Y, Nathanson KL, Herlyn M. CRAF inhibition induces apoptosis in melanoma cells with non-V600E BRAF mutations. 
Oncogene. 2009; 28:85-94. https://doi.org/10.1038/ onc.2008.362.

54. Fofaria NM, Frederick DT, Sullivan RJ, Flaherty KT, Srivastava SK. Overexpression of Mcl-1 confers resistance to BRAFV600E inhibitors alone and in combination with MEK1/2 inhibitors in melanoma. Oncotarget. 2015; 6:40535-56. https://doi.org/10.18632/oncotarget.5755.

55. Pratilas CA, Hanrahan AJ, Halilovic E, Persaud Y, Soh J, Chitale D, Shigematsu H, Yamamoto H, Sawai A, Janakiraman M, Taylor BS, Pao W, Toyooka S, et al. Genetic predictors of MEK dependence in non-small cell lung cancer. Cancer Res. 2008; 68:9375-83. https://doi. org/10.1158/0008-5472.CAN-08-2223.

56. Joshi M, Rice SJ, Liu X, Miller B, Belani CP. Trametinib with or without vemurafenib in BRAF mutated non-small cell lung cancer. PLoS One. 2015; 10:e0118210. https://doi. org/10.1371/journal.pone.0118210.

57. Martin TD, Samuel JC, Routh ED, Der CJ, Yeh JJ. Activation and involvement of Ral GTPases in colorectal cancer. Cancer Res. 2011; 71:206-15. https://doi. org/10.1158/0008-5472.CAN-10-1517.

58. Spreafico A, Tentler JJ, Pitts TM, Tan AC, Gregory MA, Arcaroli JJ, Klauck PJ, McManus MC, Hansen RJ, Kim J, Micel LN, Selby HM, Newton TP, et al. Rational combination of a MEK inhibitor, selumetinib, and the Wnt/calcium pathway modulator, cyclosporin $\mathrm{A}$, in preclinical models of colorectal cancer. Clin Cancer Res. 2013; 19:4149-62. https://doi.org/10.1158/1078-0432. CCR-12-3140.

59. Yang H, Higgins B, Kolinsky K, Packman K, Bradley WD, Lee RJ, Schostack K, Simcox ME, Kopetz S, Heimbrook D, Lestini B, Bollag G, Su F. Antitumor activity of BRAF inhibitor vemurafenib in preclinical models of
BRAF-mutant colorectal cancer. Cancer Res. 2012; 72:77989. https://doi.org/10.1158/0008-5472.CAN-11-2941.

60. Garon EB, Finn RS, Hosmer W, Dering J, Ginther C, Adhami S, Kamranpour N, Pitts S, Desai A, Elashoff D, French T, Smith P, Slamon DJ. Identification of common predictive markers of in vitro response to the Mek inhibitor selumetinib (AZD6244; ARRY-142886) in human breast cancer and non-small cell lung cancer cell lines. Mol Cancer Ther. 2010; 9:1985-94. https://doi.org/10.1158/1535-7163. MCT-10-0037.

61. Pratilas CA, Hanrahan AJ, Halilovic E, Persaud Y, Soh J, Chitale D, Shigematsu H, Yamamoto H, Sawai A, Janakiraman M, Taylor BS, Pao W, Toyooka S, et al. Genetic predictors of MEK dependence in non-small cell lung cancer. Cancer Res. 2008; 68:9375-83. https://doi. org/10.1158/0008-5472.CAN-08-2223.

62. Shahi RB, De Brakeleer S, De Grève J, Geers C, In't Veld P, Teugels E. Detection of EGFR-TK domain-activating mutations in NSCLC with generic PCR-based methods. Appl Immunohistochem Mol Morphol. 2015; 23:163-71. https://doi.org/10.1097/PDM.0000000000000035.

63. Kitagawa M, Aonuma M, Lee SH, Fukutake S, McCormick F. E2F-1 transcriptional activity is a critical determinant of Mdm2 antagonist-induced apoptosis in human tumor cell lines. Oncogene. 2008; 27:5303-14. https://doi. org/10.1038/onc.2008.164.

64. Newhouse BJ, Wenglowsky S, Grina J, Laird ER, Voegtli WC, Ren L, Ahrendt K, Buckmelter A, Gloor SL, Klopfenstein N, Rudolph J, Wen Z, Li X, Feng B. Imidazo[4,5-b]pyridine inhibitors of B-Raf kinase. Bioorg Med Chem Lett. 2013; 23:5896-99. https://doi. org/10.1016/j.bmcl.2013.08.086. 